\title{
The Realization of Kinship Terms in Persian and Filipino
}

\author{
Nazli Azodi \\ Department of Foreign Languages, Isfahan (Khorasgan) Branch \\ Islamic Azad University, Isfahan, Iran \\ Tel: 98-91-3101-1273 E-mail: azodi_n@yahoo.com \\ Fateme Karimi \\ Department of Foreign Languages, Isfahan (Khorasgan) Branch \\ Islamic Azad University, Isfahan, Iran \\ Tel: 98-91-1336-5493Ｅ-mail: fatinaz.karimi@yahoo.com
}

Received: Jan. 23, 2017 Accepted: April 4, 2017 Published: May 1, 2017

doi:10.5296/jse.v7i2.10540 URL: https://doi.org/10.5296/jse.v7i2.10540

\begin{abstract}
Sociolinguistics studies of language forms and functions should be an indispensable part of second/foreign language learning. Family or kinship address terms as an important feature of interface between language and society, can provide valuable sociolinguistic information about the interlocutors and their relationships. In line with the studies of these terms during the past few decades, this paper focuses on collecting and explaining different types of kinship terminology that Persian and Filipino interlocutors use in their conversations. The relevant terms have been collected by observation and interview. The study also highlights the differences between the two languages in using such terms based on social and cultural status. The findings of the study show that Persian is a gender sensitive and a dynamic language while Filipino is a sex-neutral and respect oriented language.
\end{abstract}

Keywords: Kinship terms, sociolinguistics, interlocutor 


\section{Introduction}

Establishing social relationship between individuals is perhaps the first step to every communicative event. To do so, people may choose different techniques to open, further, maintain, or close conversations. One important issue in studying communication is to learn how individuals manage to open conversations or how people may address one another in a given language.

Forms of address have their roots in sociocultural context of a society. Oyetade (1995) defines address terms as words or expressions used in interactive, dyadic and face-to-face situations to designate the person being talked to. Leech (1999) considers that terms of address are an important formulaic verbal behavior well recognized in the sociolinguistic literature as they signal transactional, interpersonal and deictic ramifications in human relationships. To Afful (2006a) "terms of address constitute an important part of verbal behavior through which the behavior, norms and practices of a society can be identified". Other scholars also consider the study of address terms a fruitful field for sociolinguistics due to the fact that it shows how interpersonal relationships can be socially and strategically constructed (Fitch 1991, Morford 1997).

Address terms in different speech communities are worth studying. They are likely to be different because different languages have different linguistic resources to express what is culturally permissible and meaningful. Moreover, speakers use address terms to negotiate or transform a cultural system (Fitch 1991, Morford 1997) and issues such as sexuality, age, ethnicity and religion can also be inferred and realized from address terms (Afful 2006a).

Address terms are strongly believed to manifest interpersonal relationships, the subject that has attracted many sociolinguists' attention all around the world especially in European languages. In this regard, the present study is an attempt to review the form of kinship address terms in Persian and Filipino.

The findings of this study are expected to be beneficial to linguists in general and also to those who are interested in the fields of sociolinguistics and the sociology of language.

\section{Conceptual Framework and Review of the Related Literature}

Throughout the past decades, with a considerable depth and varying issues sociolinguists have been deeply concerned with exploring different dimensions in selection of address terms. As a classic study in sociolinguistics, Brown and Gilman (1960) pronominal address system highlighted the semantic power and solidarity in relation to address terms. Since then good numbers of studies, with much broader scope and depth, have emerged. Brown and Ford (1964) focused on intimacy and status, Hymes (1967) studied social distance, Pride (1971) approached formality and informality and Moles (1974) explored confidence and respect. Consequent studies on address terms focused on other languages and support the view that address forms identify and construct cultural beliefs (Evans-Pritchard 1964, Manjulakshi 2004, Koul 1995 among others). 
Similarly, Hudson (1980) points out that an important dimension of variation in address terms has to do with cultural patterns that hold for some particular population in general due to their social values, beliefs and customs.

Keshavarz (1988) conducted a study of the forms of address in post-revolutionary Iran. In search for the political function of address terms, he reports that the revolution in Iran resulted in the choice of address terms indicating solidarity and the need to express solidarity led to greater use of terms like 'bother' and 'sister'.

Exploring Kashmiri language, Koul (1995) points out that a study of terms of address in any language plays a very important role in socio-linguistic research. He further continues that these terms are determined by certain factors as social structure, cultural pattern and geographical setting. "The role of human beings varies in a particular society according to the requirements of that society [...] the modes of address are determined by socio-economic status, literacy level, caste, age and sex." He continues that the selection of modes of address is influenced by different historical and social factors as well.

Manjulakshi (2004) also notes that terms and modes of address are important in any society for purposes of identification and expression of ideas. To her, the use of these terms depends upon the social rank, age, and the sex of the persons involved in any communicative situation.

Wardhaugh (2006) also notes that a variety of social factors usually governs our choices of terms. Among these social factors are the particular occasion, the social status or rank of the other, sex, age, family relationships, occupational hierarchy, transactional status, such as a doctor-patient relationship or priest-penitent, race, and the degree of intimacy.

As far as the scope of the studies is concerned Afful (2006a) notes that studies in sociolinguistics used to be limited to domestic or familial settings. He also thinks that "more recently, studies of address terms (sometimes aided by discourse analysis) are beginning to make forays into other social processes and practices such as politics and religion suggesting the vitality of address terms". He claimed that the influence of Westernism and modernism was reflected in the use of personal names and catch phrases. "With differing levels of frequency and saliency, the use of these terms was dictated by sociocultural factors such as gender, status, age and relationship of interactants as well as pragmatic factors" (ibid). He further asserts that the findings of address term studies have implications for theory, intercultural communication and further research.

Address forms are a universal part of human communication. No one can avoid addressing in interaction. Though all nations use addressing terms and common rules, and regulations may be found behind different addressing systems, the norms of what is appropriate to say to whom and under which conditions an address form is rated as "correct" vary greatly from nation to nation, or to be more exact, from culture to culture, showing considerable variation from one language group to another but within one language group as well.

It is very likely that some address forms are just unique in a particular culture and may even differ greatly from those of other cultures. This phenomenon has important implications for 
language learning and for intercultural communication in general. If we don't understand the address form system of the opposite interlocutors from other cultures, misunderstanding will arise.

It is not only acceptable but even normal for one person to receive many different addresses from different speakers: a teacher could be addressed as "Mrs. Dillon" by her pupils, as "Sarah" by her colleagues, as "Sal" by her family, and as "Mom" by her children. (Dickey, 2002, p.8) Consequently, we have the various kinds of address forms. Though an address system is subject to diversification and complication, people still try to classify them. TianHuigang (1998), a Chinese scholar, classifies it into five sub-categories: kinship terms, social addressing terms, names, pronouns, and polite addressing terms. Quirk (1985) uses the term "vocative", which is divided into seven sub-groups: kinship terms, occupational terms, titles, honorific terms, general nouns, epithets and pronouns.

\section{Kinship Terms}

People in any society or culture use language in daily living to refer to various kinds of kin. In sociolinguistic studies of language, there is a considerable literature on kinship terminology, describing how people in various parts of the world refer to relatives by blood (or descent) and marriage. Contemporary sociolinguistics is concerned with establishing the connection between language and culture. A study of forms of address may be a reliable way of establishing this connection. Many people are addressed and referred to by their ordinary personal names, nicknames and other special names.

Kinship systems are a universal feature of languages, because kinship is so important in social organization. Some kinship systems are much richer than others, but all make use of such factors as gender, age, generation, blood, and marriage in their organization. In any language or social organization, people use address terms to refer to various kinds of kin. However, every language necessarily creates and uses different address terms to describe particular kin relationships as identified in its own culture.

Family address terms reflect interpersonal relationships as identified and expressed in a particular culture, the learning of language-specific terms (i.e., language-specific lexical items) themselves without understanding the appropriate or accurate use of such terms is not sufficient enough for the acquisition of such terms. Thus, second/foreign language acquisition is understood as learners' knowledge of certain specific target language items (i.e., language forms), including vocabulary and grammatical rules, and their appropriate use of them (i.e., language functions). Without understanding the social and cultural aspects of family address terms and variations in using them in particular speech contexts, learners may know the relevant addressing forms but fail to use them appropriately.

Kinship terms are, above all, known for their possible complexity when it comes to denoting the exact kind of relationship between people: where one language, like English, just has the term 'uncle', another might have one for father's older brother, one for father's younger brother, one for the husbands of father's sister, and of course completely different words for the same kind of relation on the mother's side. Kinship systems have been well described as 
one of the earliest and certainly the most famous study being that of Lévi-Strauss $(1949 / 1969)$.

These terms, however, cannot only be used in order to describe more or less complicated degrees of relationship within an extended family. They can, apart from that, be found in rather unexpected circumstances, being used in order to either address (vocative use) or speak about (referential use) non-related human beings. "Vocative uses, by definition, must have second-person referents, referential uses, on the other hand, may have first, second, and third person referents: in certain languages and certain social contexts, kin terms may be used in lieu of first and second person pronouns." (Dahl/Koptjevskaja-Tamm 2001: 203).

Probably the best-known language of this sort is Mandarin (cf. e. g. Song Xuan 1997). However, the phenomenon is far from being as "exotic" - at least from an English-speaking point of view - as the mentioning of Chinese might lead us to think: vocative and referential uses of kinship terms cannot only be found in numerous non-Indo-European languages like Vietnamese, Thai, Uygur or Turkish; it also occurs in languages like Persian, Serbian or even German. Still, the functions of this kind of reference are quite diverse.

\section{The Study}

In line with the above-mentioned theoretical and research based views, this paper attempts to present and, to some extent, explain the linguistic resources available to Persian and Filipino kinship terms. In so doing, the study intended to extract the range of kinship terms which Persian and Filipino interlocutors use in different circumstances. To capture a corpus of kinship terms for these two groups, the researcher made observations of the terms which Iranian male and female interlocutors use to call their relatives in different contexts and also interviewed with two Philippinos in order to collect the related terms in this regard.

\subsection{Persian Kinship or Family/Relative Terms}

A good number of Persian address terms indicate the family relationships among individuals.

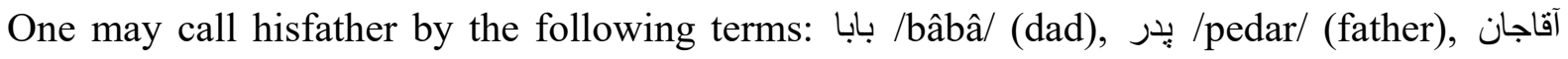
/âghajân/ (dear Mr.), بابايى /bâbâii/ (daddy), باباجان /bâbâjân/ (dear dad); Mothers may be

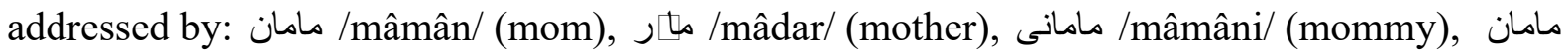

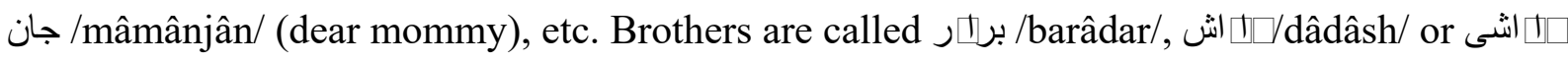
/dâdâshi/ (brother), خانصاش / خان /khândâdâsh/ (great brother), and also by their first name. Sisters

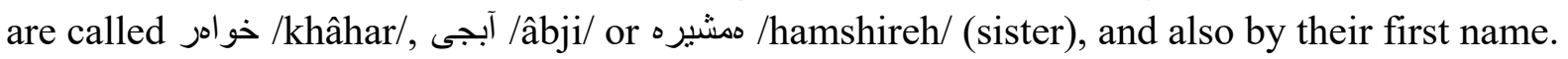

It deserves to notice that in Persian there are two words for 'aunt' and two for 'uncle' which

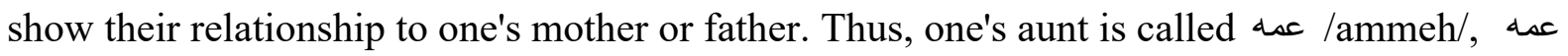

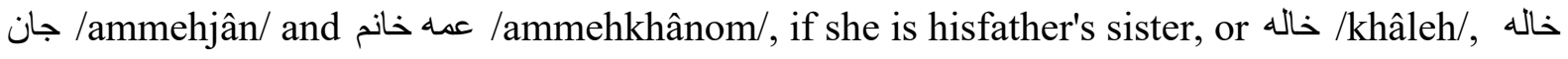
جان/khâlehjân/ and خاله خانم/kâlehkhânom/, if she is his mother's sister. Uncles, i.e. father's brother, are called عمو /amoo/, عمو جان/2hamoojân/, خان عمو/2hamoo/, and uncles, i.e.

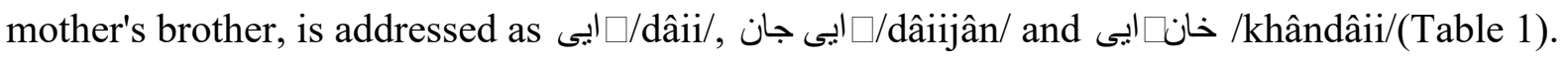


Table 1. Persian Kinship Terms for Aunt and Uncle

\begin{tabular}{|c|cc|cc|}
\hline & \multicolumn{2}{|c|}{ Sister } & \multicolumn{2}{c|}{ Brother } \\
\hline Mother's & \multicolumn{2}{|c|}{ خاله } & /khaleh/ & \multicolumn{2}{|c|}{ / dâii/ } \\
\hline Father's & عمد /amoo/ & /ammeh/ & /amoo/ \\
\hline
\end{tabular}

Consequently, for the cousins, Persian speakers use both gender referenced term and a kinship term to call a cousin. Cousins are called خترخاله/dokhtarkhâleh/ (daughter of one's mother's sister), بسرخاله/pesarkhâleh/ (son of one's mother's sister), بپرايى/pesardâii / (son of one's mother's bother), ايى $\square$ ايى /dokhtardâii/(daughter of one's mother's brother), (عمه ختر /dokhtarammeh/ ( daughter of one's father's sister), بسر عمه /pesarammeh/ (son of

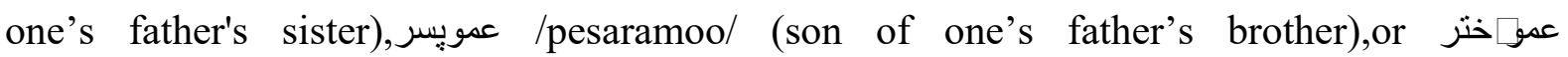
/dokhtaramoo/ (daughter of one's father's brother) (Table 2).

Table 2. Persian Kinship Terms for Cousin

\begin{tabular}{|c|c|c|}
\hline & Maternal & Paternal \\
\hline Brother's son & / pesardâii/ & 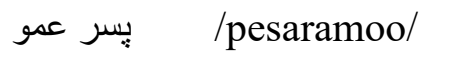 \\
\hline Brother's daughter & 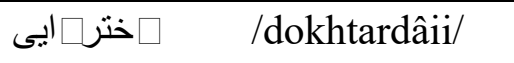 & 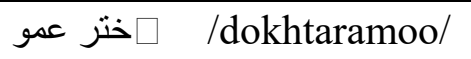 \\
\hline Sister's son & /pesarkhaleh/ & /pesarammeh/ \\
\hline Sister's daughter & $\begin{array}{l}\text { ختر } \quad \text { dokhtarkhaleh/ } \\
\text { خاله }\end{array}$ & $\begin{array}{c}\text { ختر عمه } \square \\
\text { /dokhtarammeh/ }\end{array}$ \\
\hline
\end{tabular}

On the other hand, there are no equivalent terms for niece and nephew in Persian. They call

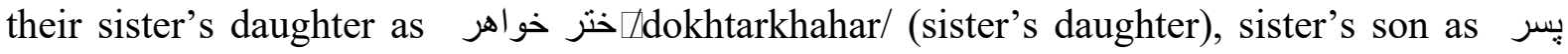
خواهر/pesarkhahar/ (sister's son), brother's daughter as ختر برلاهر/dokhtarbaradar/ (brother's daughter), and brother's son as بّر برل /pesarbaradar/ (brother's son) (Table3).

Table 3. Persian Kinship Terms for Niece and Nephew

\begin{tabular}{|c|c|c|}
\hline & Daughter & Son \\
\hline Sister's & $\begin{array}{l}\text { ختر اهر } \\
\text { /dokhtarkhahar/ }\end{array}$ & 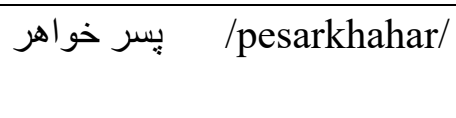 \\
\hline brother's & 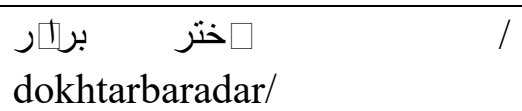 & 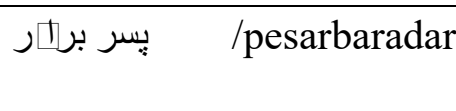 \\
\hline
\end{tabular}


Persian speakers call their grandfathers بابابزرگ /bâbâbozorg/ (granddad), بدربزرى /pedarbozorg/ (grandfather), بدرجان/pedarjân/, بقابان جان /âghâjân/, etc. Grandmothers are called:

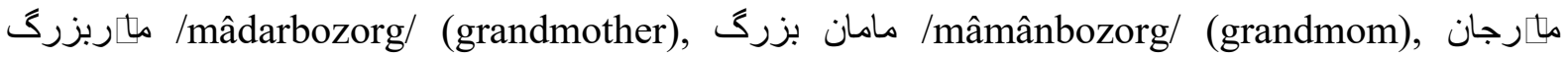
/mâdarjân/, خانم جان /khânomjân/, ننه /naneh/, and بى بـ مان /bibi/.

\subsection{Filipino Kinship or Family/Relative Terms}

Kinship terms have been classified differently in different languages. In Philippine, one may call his father /Ama/ or /Tatay/ and his mother /Ina/ or / Nanay/. Brothers are called /Kapatid/, /Na lalaki/, and /Lalaking/. Sisters are called /Kapatid/, /Na babae/, and /Babaing/. First name can be used for younger sisters or brothers. There are still specific terms for sisters and brothers which are categorized based on the age of the siblings. /Ate/ is used for the elder sister, and accordingly /Kuya/ for the elder brother, /Nene/and /BunsongBabae/ for the youngest sister, /Toto/and /Bunsong Lalake/ for the youngest brother.

Unlike Persian, there are no different terms for maternal and paternal aunt and uncle. Uncles are called /Tiyo/ and / Tito/. Aunts are called /Tiya/ and /Tita/.

Following the above mentioned patterns, they may call their cousins as /pinsan/. While male cousins can be called /Na lalaki/, /Pinsang/, and /Lalaki/, female cousins might be called / Na babae/, /Pinsang/, and /Babae/.

Again unlike Persian, Filipino speakers have equivalent terms for niece and nephew. Niece is called /PamangkingBabae/ and nephew is called/PamangkingLalake/.

Filipino speakers call their grandparents /Nuno/, grandfather as /Lolo/, and grandmother as /Lola/.

It is worth mentioning the way Filipinos call their parents' aunts and uncles. In Philippine one may call his mother's or father's aunt as /Lola/ (grandmother) and mother's or father's uncle as /Lolo/ (grandfather). Consequently, the female child of this /Lola/ and /Lolo/ is called aunt /Tiya/ or /Tita/ and the male one will be uncle /Tiyo/ or /Tito/.

\section{Discussion and Conclusion}

In order to compare and explain the kinship terminologies both in Persian and Filipino, a number of terms used in addressing the relatives among Persian and Filipino speakers were collected by observation and interview. With respect to the data of the study, some important points can be underlined.

Kinship is known as a cultural system and has a critical role in the study and analysis of a community of people. It must be noted that kinship terminologies primarily have to do with social categories and they are based on classification of genealogically specified relationships traced through genitor and genitrix (biological father and mother). By studying the kinship terms among Persian speakers, it can be concluded that they are gender sensitive. This sensitivity has its roots in their cultural, social, and religious status.Another distinctive feature of Persian which is revealed by these terminologies istheir strong connection and dependence on the family relations and ties. In addition, the usage of new terms such as بابايى /bâbâii/ and 
مامانى /mâmâni/ shows this language is dynamic enough to comply with the sociocultural changes in its speech communities.

On the other hand, analyzing kinship terms used among Filipino speakers show that they are less gender sensitive comparing to Persian ones and they are sex-neutral. The Filipino speakers have not developed institutionalized male and female principles; and they do not consider the sexes as harboring separate significances. Another point which can be pinpointed here is the matter of age consideration in their kinship terms. As it is mentioned before, some terms are used to show that the person addressed is younger or older. This kind of terminology indicates the importance of politeness and courtesy in their familial relationships. The use of such address forms also indicates the role relationship, social distance scale and age of the speakers. The importance of politeness is reflected in the use of address forms. Such appropriate address forms does not only reflect politeness but it enhances the relationship between the interlocutors.

All in all, this study suggests that foreign language learning can never be separated from foreign cultural learning. Every language has its own particular ways of realizing the social and interpersonal relationships among speakers living in the same speech community. Kinship terms are one of the linguistic means by which such relationships are expressed.

Last but not least, not only cross-linguistic differences but also cross-cultural differences can be potential sources of learner errors. Without understanding the cultural aspects of specific target language items, learners will remain at the superficial level of foreign language acquisition, and such an acquisition is of no real value in terms of learners' communicative competence. Acculturation should be an indispensable part of second/foreign language learning process.

\section{References}

Afful, Joseph B. A. (2006a). Address terms among university students in Ghana. A case Study.InJournal of Language and Intercultural Communication 6(1), 76-91. https://doi.org/10.1080/14708470608668909

Afful, Joseph B. A. (2006b). Non-kinship address terms in Akan. A sociolinguistic study of language use in Ghana.InJournal of Multilingual and Multicultural Development, 27(4), 275-289. https://doi.org/10.2167/jmmd425.1

Aliakbari, M., \& Toni, A. (2008). The Realization of Address Terms in Modern Persian in Iran: A Sociolinguistic Study. In Linguistic Online, 2008, 35(3), 3-12.

Brown, R., \& Gilman, A. (1960).The pronouns of power and solidarity. In Sebeoki, Thomas A. (ed.): Style in language. Cambridge, MA, 253-276.

Evans-Pritchard, \& Edward E. (1964). Nuer modes of address. In Hymes, Dell H. (ed.): Language in culture and society. New York: 221-227. 
Fitch, Kristine L. (1991). The interplay of linguistic universals and cultural knowledge in personal address.Columbian Madre terms.In Communication Monographs, 58, 254-272. https://doi.org/10.1080/03637759109376229

Fitch, Kristine L. (1998). Speaking Relationally: Culture, Communication, and Interpersonal Connection. In New York: Guilford.

Gao, Ch. (2013). A Contrastive Study of Chinese and English Address Forms. In Theory and Practice in Language Studies, 3(1), 190-194. https://doi.org/10.4304/tpls.3.1.190-194

Hentschel, E. (2012). All men become brothers. The use of kinship terms for non-related persons as a sign of respect or disrespect. In Linguistic Online, 51(1), 40-43.

Hudson, Richard A. (1980). Sociolinguistics. New York.

Hymes, Dell H. (1967). Models of interaction of language and social setting.In Journal of Social Issues 23(2), 8-28. https://doi.org/10.1111/j.1540-4560.1967.tb00572.x

Keshavarz, M. H. (1988). Forms of address in post-revolutionary Iranian Persian.A sociolinguistic analysis.Language in Society, 17, 565-575. https://doi.org/10.1017/S0047404500013105

Koul, O. N. (1995). Personal Names in Kashmiri.InKoul, Omkar N. (ed.) Sociolinguistics.South Asian Perspectives. New Delhi.

Leech, Geoffrey. (1999). The distribution and function of vocatives in American and British English conversation. In Hasselgard, Hilde/Oksefjell, Signe (eds.). Out of Corpora. Studies in honor of Stig Johansson. Amsterdam, 107-118.

Manjulakshi, L. (2004). Modes of address in Kannada: A sociolinguistic study of language use in Mysore District. Available at: http://www.languageinindia.com/sep2004/manjulakshitermsofaddress1.html_ (accessed September 2008).

Morford, Janett. (1997). Social indexicality in French pronominal address.InJournal of Linguistic Anthropology, 7, 3-37. https://doi.org/10.1525/jlin.1997.7.1.3

Oyetade, Solomon Oluwole (1995). A sociolinguistic analysis of address forms in Yoruba. In Language in Society, 24, 515-535. https://doi.org/10.1017/S004740450001900X

Pride, John B. (1971). Formal and informal language.An inaugural address. Wellington. Wardhaugh, Ronald (2006): An introduction to sociolinguistics. 5th ed. Oxford.

Quirk, R. (1985). A Grammar of Contemporary English. London: Longman.

Tian, H. (1998). Address Systems in Western Countries and China. Beijing: Foreign Language and Teaching Research Press.

Wardhaugh, R. (2006). An introduction to sociolinguistics. 5th ed. Oxford. 


\section{Macrothink}

Journal of Studies in Education

ISSN 2162-6952 2017, Vol. 7, No. 2

Wolfram W, \& Schilling-Estes N. (1998). American English: Dialects and Variation. Oxford: Blackwell.

Xuexin, L. (2004). Politeness as a Social Strategy in Japanese Culture. In Metraus. Daniel, A., Ted. Southeast Review of Asian Studies, VI, 71-96. (=A[ Publication of Southeast Conference Association for Asian Studies, 2004: 78). 